\title{
PEMODELAN SPASIAL EPIDEMIOLOGI DEMAM BERDARAH DENGUE MENGGUNAKAN SISTEM INFORMASI GEOGRAFI DI KECAMATAN DEPOK KABUPATEN SLEMAN YOGYAKARTA
}

\author{
Prima Widayani \\ prima.widayani@gmail.com \\ Program Studi Kartografi Penginderaan Jauh \\ Jurusan Sains Informasi Geografi dan Pengembangan Wilayah \\ Fakultas Geografi UGM
}

\begin{abstract}
The objective of this research is for developing a prototype of Dengue Haemorrhagic Fever Epidemiologic Spatial Modeling to define the irritable area rates for that disease. The research is conducted at Depok, Sleman, Yogyakarta. The model's made by GIS with overlaying 8 parameters: population density, the cleaning activity frequency of water vessel, waste management pattern, frequency of fogging, drainage condition, settlement pattern, distance settlement from river, and survillance. Each parameter's analyzed by cross tabs analyze to see its correlation with the actual case. The result from this analyze is used to give weighting factors for those parameters. The research finding show that 8 parameters have partial correlation with actual case of dengue fever. The result model is tested again with the actual dengue fever case. As we can see from crosstab test, the value of $C$ (coefficient contingency) $=0,558$. So the research gives a meaningful test, and we can take conclusion that there's a real correlation between dengue fever irritable model and actual dengue fever case.
\end{abstract}

Key words: Spatial modeling, epidemiology, dengue haemorrhagic fever

\section{PENDAHULUAN}

\section{Latar Belakang}

Wilayah Indonesia memiliki sumberdaya alam dan keanekaragaman hayati yang tinggi, namun Indonesia juga kaya akan bencana yang kerap menimpa beberapa wilayah di Indonesia. Bencana terus menimpa Indonesia akhir-akhir ini, mulai dari bencana alam banjir, tanah longsor, kebakaran hutan, gunung meletus, kekeringan, gempa bumi dan tsunami menimpa beberapa wilayah di Indonesia. Bencana tersebut menimbulkan korban jiwa dan harta benda yang tidak sedikit nilainya. Menurut WHO, difinisi bencana adalah setiap kejadian yang menyebabkan kerusakan, gangguan ekologis, hilangnya nyawa manusia atau memburuknya derajat kesehatan atau pelayanan kesehatan pada skala tertentu yang memerlukan respon dari luar masyarakat atau wilayah yang terkena. Dari difinisi diatas dapat ditarik kesimpulan bahwa yang dinamakan bencana tidak hanya bencana alam, tetapi kejadian Kejadian Luar Biasa (KLB) juga dapat dikategorikan sebagai bencana. Kejadian Luar Biasa yang pernah terjadi di Indonesia antara lain Demam Berdarah, Diare, Polio. 
Sejak dari dulu awal ditemukannya penyakit demam berdarah di Indonesia pada tahun 1968 hingga sekarang, penyakit ini banyak menelan korban jiwa. Pemberantasan penyakit ini terus menerus diupayakan untuk mengurangi angka kematian dengan berbagai macam program yang dicanangkan oleh pemerintah seperti Program 3M PLUS (menguras, mengubur barang yang tidak dipakai, menutup tempat penampungan air, plus menghindari gigitan nyamuk), pengasapan (fogging), pembentukan jumantik, pembagian abate, dan program program lainnya. Namun tetap saja penyakit ini masih sulit dikendalikan bahkan dari hasil penelitian yang dilakukan oleh Fakultas Kedokteran UGM menyebutkan bahwa beberapa nyamuk sudah memiliki resistensi terhadap insektisida yang digunakan sebagai bahan fogging. Hal ini sungguh sangat menyulitkan bagi kita untuk menghentikan populasi nyamuk. Sebenarnya hingga saat ini kegiatan yang masih dirasa efektif untuk menekan populasi nyamuk Aedes aegypti adalah memutus mata rantai perkembangbiakannya, yaitu dengan usaha dan kesadaran dari masyarakat untuk tidak menyediakan sarana atau wadah bagi perkembangbiakan nyamuk ini.

Sistem Informasi Geografis memiliki peran penting dalam siklus manajemen bencana, mulai dari pencegahan, mitigasi, tanggap darurat hingga rehabilitasi. Peta merupakan salah satu cara terbaik untuk memvisualisasikan hasil penilaian kerawanan (vulnerabilitas). Peta dapat memadukan dimensi keruangan (spasial), karakteristik dari hazard serta berbagai informasi lainnya seperti gambaran lingkungan maupuan data masyarakat yang relevan.

Pada saat dan setelah bencana terjadi, berbagai aktivitas kesehatan harus dilakukan untuk mengatasi masalah kesehatan para korban serta mencegah memburuknya derajat kesehatan masyarakat yang terkena bencana. Pada tahapan tanggap darurat, energi yang cukup besar biasanya dicurahkan untuk evakuasi korban. Kegiatan lain yang juga sudah harus dimulai segera meliputi kesehatan lingkungan, surveilans dan pemberantasan penyakit, pelayanan kesehatan serta distribusi logistik kesehatan dan bahan makanan. Problem yang seringkali terjadi kemudian adalah persoalan manajemen dan koordinasi kegiatan serta sumber daya. Alokasi tenaga kesehatan, obat-obatan dan bahan makanan memerlukan informasi yang akurat mengenai jumlah populasi dan lokasi penampungan korban (Anis, 2007)

\section{Lokasi penelitian}

Kecamatan Depok merupakan salah satu kecamatan di Kabupaten Sleman Provinsi Daerah Istimewa Yogyakarta. Ditinjau secara geografis letak Kecamatan Depok berada pada $110^{\circ} 24^{\prime}$ BT sampai $110^{\circ} 28^{\prime}$ BT dan $7^{0} 46^{\prime}$ LS sampai $7^{0} 50^{\prime}$ LS. Kecamatan Depok memiliki 3 Desa yaitu Desa Caturtunggal, Desa Condongcatur dan Desa Maguwoharjo. Luas wilayah Kecamatan Depok sebesar $2832,58 \mathrm{Ha}$. 


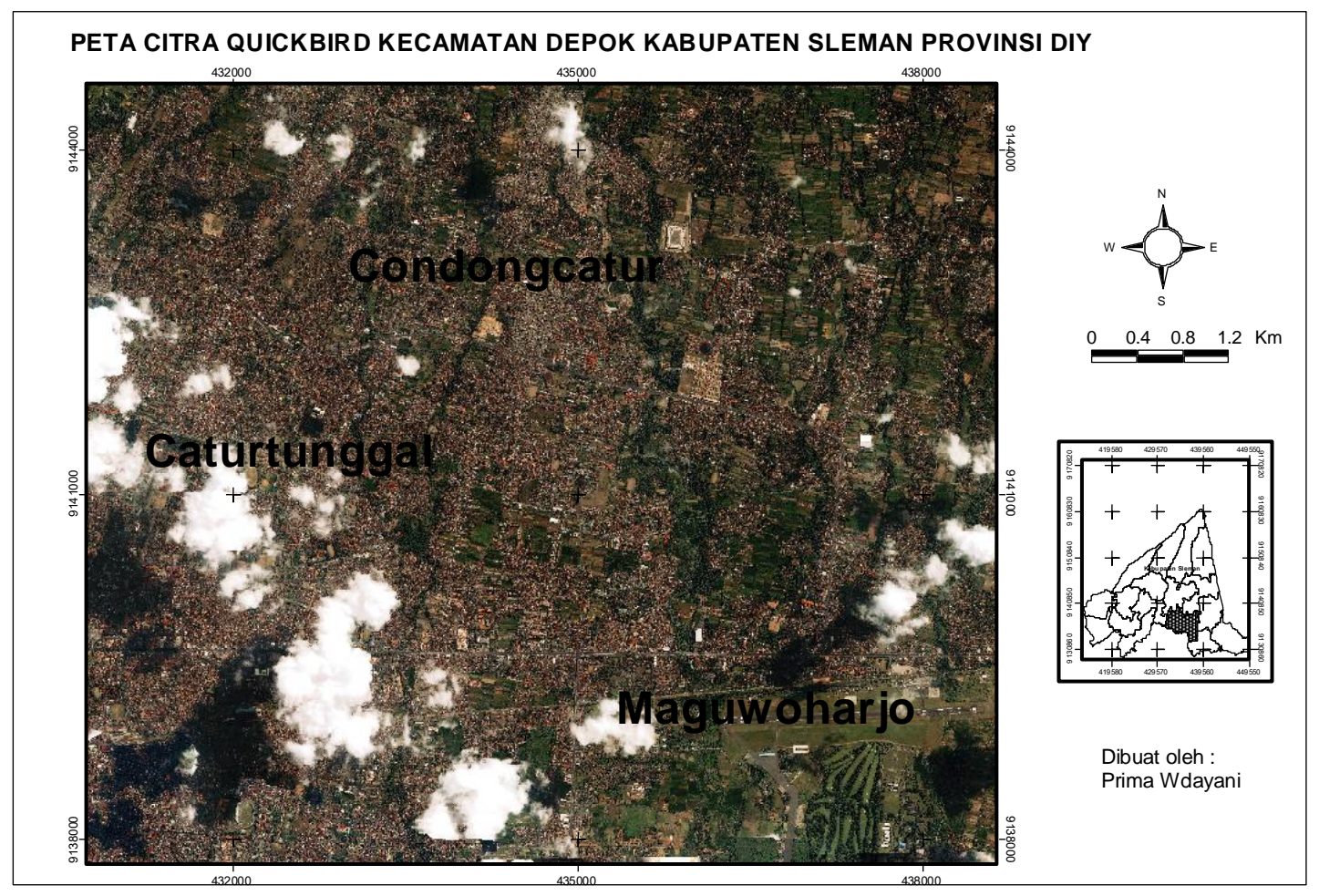

Gambar 1. Peta Citra Quickbird Kecamatan Depok

Melihat angka kejadian DBD yang tinggi di Kecamatan depok dari tahun ke tahun, maka peneliti menggunakan Kecamatan Depok sebagai daerah penelitian untuk membuat model spasial tingkat kerawanan wilayah terhadap demam berdarah. Angka kejadian di Kecamatan Depok dari tahun ke tahun selalu mengalami peningkatan jumlah penderita demam berdarah. Pada tahun 2002 jumlah penderita demam berdarah sebanyak 49 jiwa pada tahun 2003 yang merupakan Kejadian Luar Biasa di Indonesia, termasuk di Kecamatan Depok mengalami peningkatan tajam sebesar 243 penderita, angka ini terus menurun hingga tahun 2007 dan mengalami peningkatan lagi dengan jumlah penderita mencapai 200 jiwa.

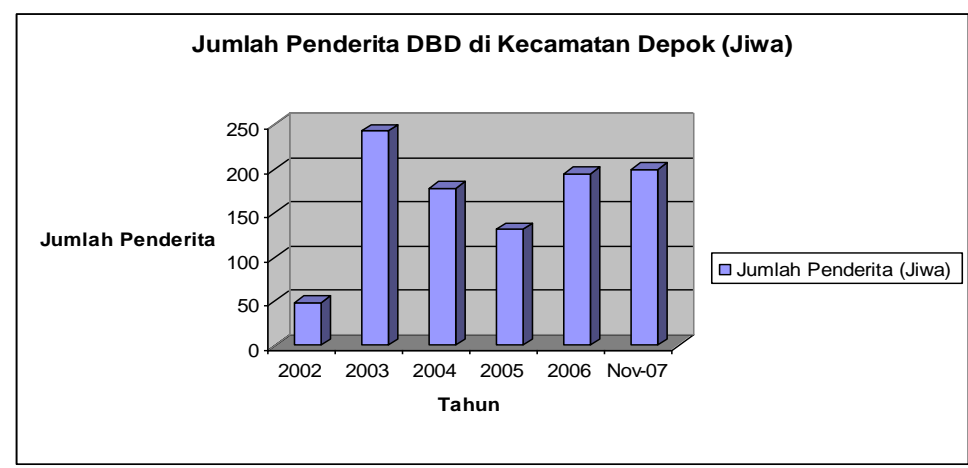

Gambar 2. Diagram Batang Jumlah penderita DBD di kecamatan depok dari Th 2002 - 2007 Sumber : Dinas Kesehatan Kab.Sleman 


\section{Tujuan Penelitian}

1. Mengetahui faktor lingkungan yang berpengaruh terhadap kejadian demam berdarah.

2. Penyusunan prototype pemodelan spasial epidemiologi demam berdarah dengue untuk menentukan tingkat kerawanan wilayah terhadap penyakit DBD dengan menggunakan Sistem Informasi Geografis.

\section{METODE PENELITIAN}

Ada beberapa tahapan yang dilakukan dalam penelitian ini yaitu, pengumpulan data, pengolahan data, survai lapangan, pembuatan peta kejadian demam berdarah (incident rate), pembuatan model dan pengujian hasil. Adapun bahan dan alat yang dibutuhkan adalah sbb :

\section{Bahan}

(1)Peta Rupa Bumi Indonesia skala 1 : 25.000, (2) Data penderita demam berdarah di Kecamatan Depok tahun 2002-2007 dari Dinas kesehatan dan Puskesmas, (3) Data blok permukiman, tata letak, kepadatan rumah, jarak lokasi permukiman dengan sungai dari hasil interpretasi citra Quickbird tahun 2007, (3) Data kondisi saluran drainase, frekwensi membersihkan bak, fogging dan keberadaan jumantik yang dipeoleh dari hasil pengamatan di lapangan

\section{Alat}

Seperangkat komputer, Plastik transparansi, OHP, GPS Garmin seri 76 CsX, dan Quesioner.

\section{Pengolahan Data}

1. Pengolahan data dari Citra Satelit Quickbird

Data yang diambil dari citra penginderaan jauh pada penelitian ini berupa data kepadatan permukiman, pola permukiman dan jarak permukiman dengan sungai. Setiap parameter yang diambil dari citra kemudian diklasifikasikan dan diberi harkat sbb :

Tabel 1. Klasifikasi kepadatan permukiman per dusun

\begin{tabular}{ccc}
\hline $\begin{array}{c}\text { Kepadatan Permukiman (luas blok } \\
\text { permukiman/luas dusun) }\end{array}$ & Kelas & Harkat \\
\hline $0,07-33,1$ & rendah & 1 \\
\hline $33,2-66,23$ & sedang & 2 \\
\hline$>66,24$ & tinggi & 3 \\
\hline
\end{tabular}

Sumber : Hasil perhitungan

Tabel 2. Klasifikasi Tata Letak dan Pola Permukiman

\begin{tabular}{llc}
\hline $\begin{array}{c}\text { Persentase } \\
\text { bangunan }\end{array}$ & \multicolumn{1}{c}{ Kriteria penilaian } & Harkat \\
\hline$>=50 \%$ & $\begin{array}{l}\text { Pola teratur, hampir semua rumah menghadap ke } \\
\text { jalan, luas kapling rumah dan bentuk rumah } \\
\text { hampir seragam. }\end{array}$ & 1 \\
& & \\
\hline
\end{tabular}




\begin{tabular}{lll}
\hline $25-50 \%$ & $\begin{array}{l}\text { Pola teratur, hampir semua rumah menghadap ke } \\
\text { jalan, luas kapling rumah dan bentuk rumah } \\
\text { hampir seragam. }\end{array}$ & 2 \\
\hline$<25 \%$ & $\begin{array}{l}\text { Pola teratur, hampir semua rumah menghadap ke } \\
\text { jalan, luas kapling rumah dan bentuk rumah } \\
\text { hampir seragam. }\end{array}$ & 3 \\
\hline
\end{tabular}

Sumber : Ditjen Cipta karya PU tahun 1979 dengan modifikasi.

Tabel 3. Klasifikasi jarak permukiman dengan sungai

\begin{tabular}{cc}
\hline Jarak dari blok permukiman & Harkat \\
\hline$\leq 100 \mathrm{~m}$ & 1 \\
\hline $101-200 \mathrm{~m}$ & 2 \\
\hline$>200 \mathrm{~m}$ & 3 \\
\hline
\end{tabular}

Sumber: Hasil perhitungan

\section{Pengolahan data dari survai lapangan}

Data yang diambil langsung di lapangan meliputi kondisi tempat pembuangan sampah, saluran drainase dan frekuensi membersihkan bak penampungan air, pengasapan (fogging), keberadaan juru pemantau jentik. Data yang diperoleh memiliki koordinat sehingga dapat dipetakan dan selanjutnya diberi harkat sbb:

Tabel 4. Klasifikasi Kondisi Pembuangan Sampah

\begin{tabular}{lc}
\hline $\begin{array}{c}\text { Persentase jumlah keluarga yang memiliki tempat sampah atau } \\
\text { diangkut dengan truk sampah }\end{array}$ & Harkat \\
\hline Ada Tempat penampungan sampah atau sampahnya diangkut $>50 \%$ & 1 \\
\hline Ada Tempat penampungan sampah atau sampahnya diangkut $25 \%-50 \%$ & 2 \\
\hline Ada Tempat penampungan sampah atau sampahnya diangkut $<25 \%$ & 3 \\
\hline Sumber : Ditjen Cipta Karya PU tahun 1979 dengan modifikasi &
\end{tabular}

Tabel 5. Klasifikasi Kondisi Saluran Drainase

\begin{tabular}{|c|c|}
\hline $\begin{array}{c}\text { Persentase penghuni permukiman pada unit pemetaan mempunyai } \\
\text { saluran darinase }\end{array}$ & Harkat \\
\hline $\begin{array}{l}>50 \% \text { penghuni permukiman pada unit pemetaan mempunyai saluran } \\
\text { darinase dan kondisinya berfungsi dengan baik }\end{array}$ & 1 \\
\hline $\begin{array}{l}25 \% \text { - } 50 \% \text { penghuni permukiman pada unit pemetaan mempunyai saluran } \\
\text { darinase dan kondisinya berfungsi dengan baik }\end{array}$ & 2 \\
\hline $\begin{array}{l}<25 \% \text { penghuni permukiman pada unit pemetaan mempunyai saluran } \\
\text { darinase dan kondisinya baik }\end{array}$ & 3 \\
\hline
\end{tabular}

Tabel 6. Klasifikasi Frekuensi Membersihkan Bak Penampungan Air

\begin{tabular}{cc}
\hline Frekuensi membersihkan bak penampungan air & Harkat \\
\hline 3 kali dalam 1 minggu & 1 \\
\hline 1 kali dalam 1 minggu & 2 \\
\hline$>$ 1 minggu baru dikuras & 3 \\
\hline
\end{tabular}

Sumber : Andianasolo 2001.

Tabel 7. Klasifikasi pengasapan (fogging)

\begin{tabular}{lc}
\hline \multicolumn{1}{c}{ Pemberian fogging tiap dusun } & Harkat \\
\hline Ada fogging dalam 1 dusun & 1 \\
\hline Ada fogging tetapi tidak menyeluruh dalam & 2 \\
\hline
\end{tabular}




\begin{tabular}{|c|c|}
\hline 1 dusun & \\
\hline Tidak ada fogging dalam 1 dusun & 3 \\
\hline \multicolumn{2}{|l|}{ Sumber : Hasil analisis } \\
\hline Tabel 8 .Klasifikasi keberadaan juru pemar & jentik \\
\hline Keberadaan Jumantik & Harkat \\
\hline Ada juru pemantau jentik dalam 1 dusun & 1 \\
\hline $\begin{array}{l}\text { Ada juru pemantau jentik tetapi tidak } \\
\text { menyeluruh dalam } 1 \text { dusun }\end{array}$ & 2 \\
\hline Tidak ada juru pemantau jentik dalam 1 dusun & 3 \\
\hline
\end{tabular}

\section{Pembuatan peta IR (Inciden Rate) atau Kejadian DBD}

Pembuatan peta kejadian demam berdarah diperoleh dengan jalan menghitung penderita demam berdarah pada tiap-tiap dusun dan kemudian dikelaskan agar diperoleh status daerah tersebut. Daerah yang memiliki IR (Inciden Rate) atau banyaknya kasus per 100.000 penduduk > 20/100.000 maka daerah tersebut dinyatakan memiliki kasus DBD tinggi. Daerah yang kasus DBDnya tinggi dapat juga dilihat dari nilai CFR (case fatality rate).

$\mathrm{CFR}=($ jumlah kematian/jumlah penderita $) \times 100$

Jika CFR > 1\% maka darah tersebut dinyatakan memiliki kasus DBD tinggi

(Departemen Kesehatan RI, 2004)

\section{Pembuatan Model}

Metode pembuatan model kerawanan wilayah dilakukan dengan metode pengharkatan/skoring. Masing-masing parameter yang diperoleh baik melalui data sekunder maupun dari kerja lapangan diberi skor dan dikalikan dengan pembobot sesuai dengan bobot yang telah ditentukan. Keseluruhan parameter kemudian ditumpang susunkan sehingga total skor dapat diketahui.

\section{Pengujian Model}

Pengujian dilakukan dengan menganalisis hasil klasifikasi kerawanan wilayah yang diperoleh dari penelitian ini dengan kasus demam berdarah yang terjadi di Kecamatan Depok. Peta tingkat kerawanan terhadap penyakit demam berdarah yang dihasilkan kemudian dianalisis terhadap distribusi penderita demam berdarah pada daerah yang sama. Peta zonasi kerawanan yang dihasilkan ditumpang susunkan dengan data penderita demam berdarah di lingkungan Kecamatan Depok sehingga baru dapat dilakukan analisis asosiasi spasial. Dari hasil tumpang susun kedua peta selanjutnya dihitung frekuensinya dan disajikan dalam bentuk tabel (crosstab). Berdasarkan tabel tersebut kemudian disusun tabel analisis yang digunakan untuk menghitung $\mathrm{C}$ (contingency coefficient). Formula yang digunakan untuk menghitung $\mathrm{C}$ (contingency coefficient) dapat dijelaskan sebagai berikut :

$$
\mathrm{C}=\sqrt{\frac{\mathrm{X}^{2}}{\mathrm{X}^{2}+\mathrm{n}}}
$$




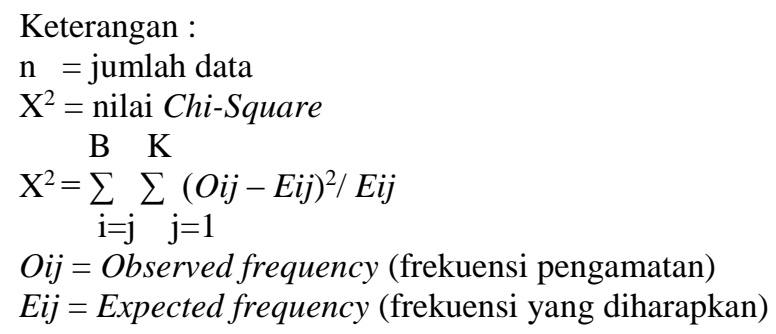

Agar harga $\mathrm{C}$ yang diperoleh dapat dipakai untuk menilai derajat asosiasi antara faktor, maka harga $\mathrm{C}$ perlu dibandingkan dengan koefisien kontingensi maksimum yang bisa terjadi. Harga $\mathrm{C}$ maksimum dihitung dengan rumus :

$$
\mathrm{C} \text { maks }=\sqrt{\frac{\mathrm{m}-1}{\mathrm{~m}}}
$$

keterangan :

$\mathrm{m}=$ harga minimum antara B (banyak baris) dan K (banyak kolom).

Menurut Sudjana (1992), hasil perbandingan antara C dan Cmaks dapat diartikan sebagai berikut :

$\mathrm{C}=0$ berarti tidak ada hubungan atau tidak ada assosiasi (no correspondence)

$\mathrm{C}=>0$ dan $<1$, berarti ada hubungan atau asosiasi sebagian (partial correspondence)

$\mathrm{C}=1$, berarti ada hubungan atau asosiasi sempurna (perfect correspondence) 


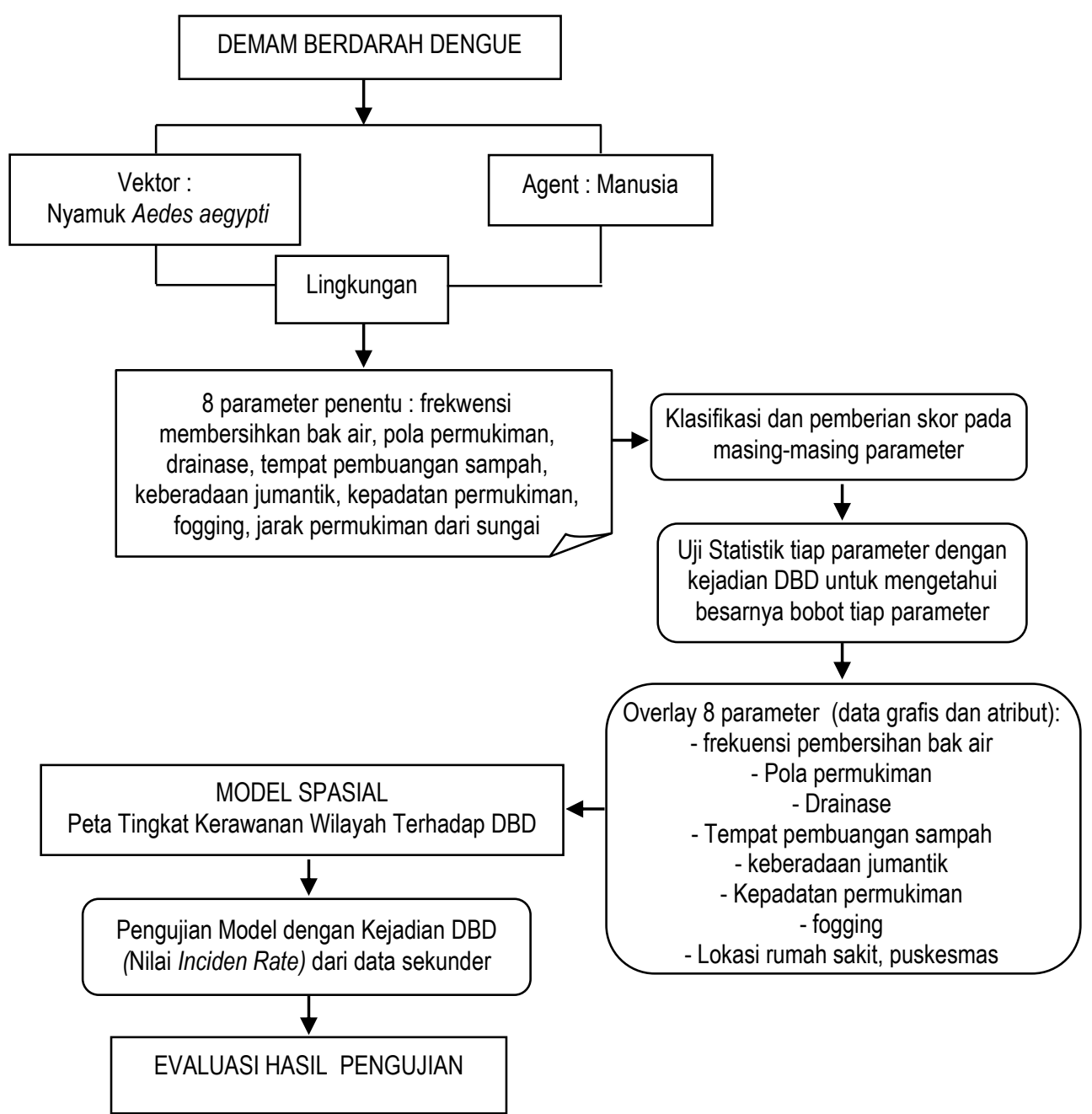

Gambar 3. Diagram alir penelitian

\section{HASIL DAN PEMBAHASAN}

Penelitian ini menghasilkan beberapa peta tematik yang merupakan parameter pembentuk model kerawanan wilayah terhadap demam berdarah, serta peta kerawanan wilayah hasil pemodelan spasial. Selain itu dari data sekunder dapat pula dipetakan kejadian demam berdarah di Kecamatan Depok selama kurun waktu dari tahun 2006 - 2007. Selain peta, hasil dari penelitian ini berupa analisis statistik hasil pengujian tiap parameter dengan data kejadian demam berdarah dan pengujian model spasial yang dihasilkan dengan data kejadian demam berdarah di Kecamatan Depok. 


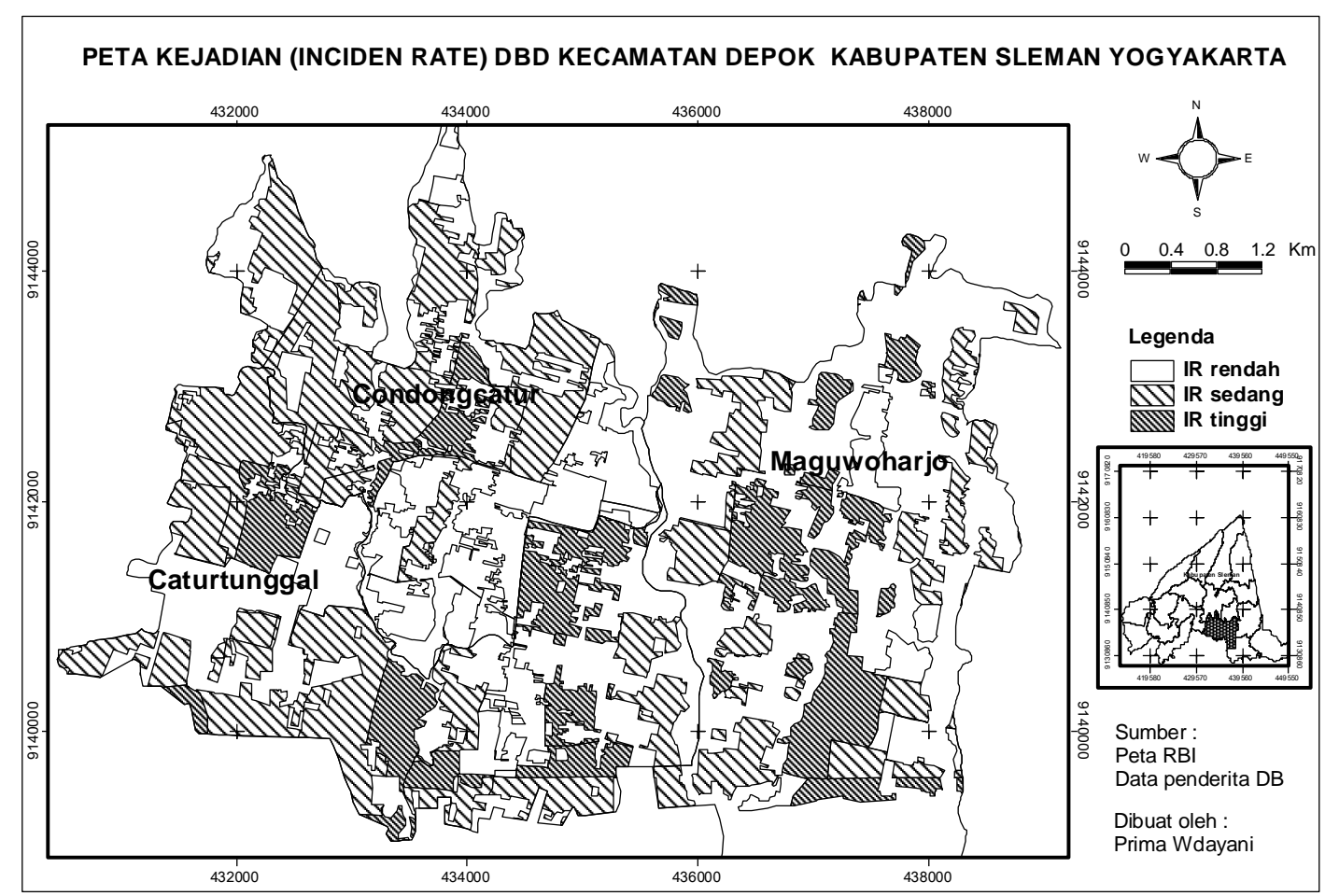

Gambar 4. Peta Kejadian (IR) Demam Berdarah di Kecamatan Depok

Berdasarkan data sekunder dari Dinas Kesehatan, maupun survai di lapangan di ketahui bahwa wilayah Desa Caturtunggal, Condongcatur dan Maguwoharjo tergolong dalam klasifikasi IR tinggi, namun pada penelitian kali ini, peneliti mencoba mengkelaskan lagi dan membaginya dalam unit-unit kecil berupa dusun untuk mengetahui dusun mana yang merupakan penyumbang kasus DBD sehingga di Kecamatan Depok memiliki IR yang tinggi. Untuk melihat status per dusun dapat dilihat pada tabel dibawah ini dan pola spasialnya dapat dilihat pada peta.

Tabel 9. Klasifikasi IR per dusun di Kecamatan Depok

\begin{tabular}{cc}
\hline Status & IR (Inciden Rate) \\
\hline Rendah & $<0,1 / 1000$ penduduk \\
\hline Sedang & $0,1 / 1000-0,9 / 1000$ penduduk \\
\hline Tinggi & $\geq 1 / 1000$ penduduk \\
\hline
\end{tabular}

Sumber : Departeman Kesehatan, 2004 dengan modifikasi

Tabel 10. Luas dan persentase kelas Incident Rate

\begin{tabular}{lcr}
\hline Klasifikasi IR & Luas (Ha) & Persentase (\%) \\
\hline Rendah & 315.84 & 18.91 \\
\hline Sedang & 914.22 & 54.72 \\
\hline Tinggi & 440.56 & 26.37 \\
\hline Total & 1670.62 & 100.00 \\
\hline Sumber: Perhitungan dan pengolahan dengan SIG
\end{tabular}


Hasil pengolahan data dan tumpang susun peta telah dihasilkan model spasial yang berupa Peta Kerawanan Wilayah Terhadap Demam Berdarah di Kecamatan Depok. Berdasarkan hasil pengolahan dan perhitungan dapat dilihat bahwa persentase terbesar adalah kelas rawan dengan total luas $829,82 \mathrm{Ha}$ atau 49,67\% dari total luas blok permukiman. Kelas sangat rawan menempati urutan kedua dengan total luas $589,87 \mathrm{Ha}$ atau $35,31 \%$. Hal ini mengindikasikan bahwa hampir di seluruh wilayah Kecamatan Depok memiliki resiko tinggi terkena penyakit demam berdarah. Karena luasanya besar, maka perlu mendapatkan penanganan dengan segera karena bisa jadi daerah tersebut makin meluas jika tidak segera dilakukan perbaikan kualitas lingkungan maupun pola hidup masyarakatnya. Sehingga daerah ini perlu mendapat prioritas penanganan I yang lebih intensif dibandingkan dengan daerah lain. Perbaikan lingkungan dan penyadaran terhadap penduduk perlu ditingkatkan. Bimbingan penyuluhan tetap perlu diberikan agar masyarakat lebih berhati-hati dan mulai tergerak untuk mengelola lingkungannya agar bebas dari jentik nyamuk. Daerah yang agak rawan memiliki luas 250,93 Ha atau $15,02 \%$ dari total luas blok permukiman. Daerah yang agak rawan ini bukan berarti telah bebas dari ancaman penyakit demam berdarah, karena jika tidak ada pengelolaan lebih lanjut bisa jadi status daerahnya akan meningkat menjadi daerah rawan bahkan sangat rawan.

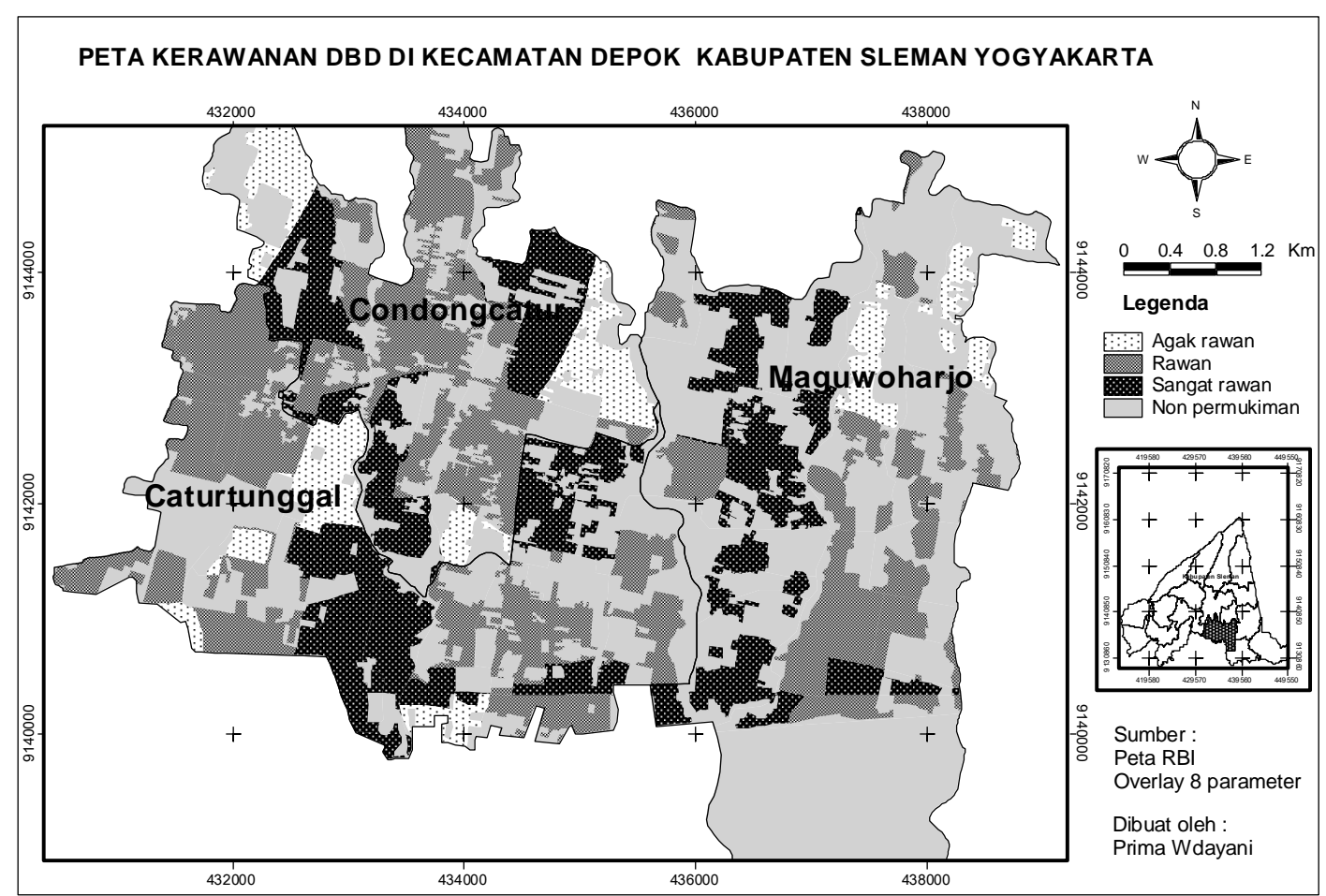

Gambar 5. Peta kerawanan DBD di Kecamatan Depok 


\section{Analisa keterkaitan antara parameter lingkungan, prilaku manusia dan upaya pencegahan dengan kejadian Demam Berdarah.}

Analisis statistik ini bertujuan untuk mengetahui hubungan antara beberapa parameter yang dipakai yaitu kepadatan permukiman, pola/tata letak permukiman, jarak permukiman dari sungai, kondisi drainase, frekuensi membersihkan bak penampungan air, tata cara pembungan sampah, pengasapan (fogging), dan keberadaan jumantik dengan kejadian demam berdarah yang ada di daerah penelitian. Hal ini diperlukan agar nantinya dalam memberikan bobot pada masing masing parameter untuk tujuan pemodelan spasial dapat diberikan secara proporsional sesuai dengan besarnya hubungan atau keterkaitan antara parameter tersebut dengan kejadian demam berdarah.

Analisis statistik yang digunakan adalah uji independen antara dua faktor atau crosstab dengan bantuan software SPSS. Berdasarkan hasil analisis akan diselidiki mengenai asosiasi atau hubungan atau kaitan antar faktor. Sebelum dilakukan analisis, masing-masing parameter yang telah dipetakan dioverleykan dengan kejadian demam berdarah yang ada di lapangan.

Setelah dilakukan analisis cosstab antara masing-masing parameter dengan kejadian demam berdarah di Kecamatan Depok, maka diperoleh hasil sebagai berikut :

Tabel 11. Hasil Analisis Statistik Dengan Crosstab (Chi Square)

\begin{tabular}{lrrr}
\hline Parameter & C(coeficien contingency) & Cmaks & \multicolumn{2}{c}{ C/Cmaks } \\
\hline Kepadatan permukiman & 0.32 & 0.816 & 0.4 \\
\hline Pola permukiman & 0.1 & 0.816 & 0.1 \\
\hline Jarak permukiman dari sungai & 0.24 & 0.816 & 0.3 \\
\hline Kondisi Drainase & 0.14 & 0.816 & 0.2 \\
\hline Frekwensi membersihkan bak air & 0.38 & 0.816 & 0.5 \\
\hline Pola pembuangan sampah & 0.14 & 0.816 & 0.2 \\
\hline Fogging & 0.33 & 0.816 & 0.4 \\
\hline Jumantik & 0.39 & 0.816 & 0.5 \\
\hline
\end{tabular}

Sumber : Hasil analisis statistik

Tabel 12 . Bobot tiap parameter berdasarkan hasil analisis statistik

\begin{tabular}{lll}
\hline No & \multicolumn{1}{c}{ Parameter } & $\begin{array}{c}\text { Bobot } \\
(\mathrm{C} / \mathrm{Cmaks}) * 10\end{array}$ \\
\hline 1. & Kepadatan Permukiman & 4 \\
\hline 2. & Pola permukiman & 1 \\
\hline 3. & Jarak permukiman dari sungai & 3 \\
\hline 4. & Kondisi saluran drainase & 2 \\
\hline 5. & $\begin{array}{l}\text { Frekuensi membersihkan } \\
\text { penampungan air }\end{array}$ & 5 \\
\hline 6. & Pola pembungan sampah & \\
\hline 7. & Pemberian Fogging & 4 \\
\hline 8. & Keberadaan Jumantik & 5 \\
\hline
\end{tabular}

Sumber : Hasil analisis statistik 


\section{Analisa Hubungan Antara Pemodelan Spasial Kerawanan Wilayah Terhadap DBD dengan Kejadian Sesungguhnya.}

Model spasial yang telah dihasilkan tidak dapat begitu saja diterima dan dipakai. Perlu pengujian lebih lanjut apakah model dapat diterima atau tidak. Pengujian dilakukan untuk melihat apakah hasil pemodelannya sudah sesuai dengan kenyataan yang terjadi di lapangan atau malah sebaliknya. Sebelum dilakukan pengujian, terlebih dahulu harus diketahui berapa jumlah penderita yang terdapat di wilayah Kecamatan Depok dan distribusinya di masing-masing Dusun. Jumlah penderita tersebut tidak bisa langsung digunakan untuk pengujian tetapi sebelumnya harus dibagi dengan jumlah penduduk yang ada di wilayah dusun tersebut dan dijadikan \%o. Artinya di setiap 1000 penduduk ada berapa penderita. Hasilnya kemudian dikelaskan lagi menjadi 3 kategori kelas yaitu wilayah dengan kategori penderita rendah, sedang dan tinggi seperti yang telah dijelaskan di atas.

Peta kerawanan terhadap DBD di Kecamatan Depok di tumpang susunkan dengan peta kejadian DBD di Kecaatan Depok. Berdasarkan hasil tumpang susun peta dapat dilakukan analisis secara spasial kecocokan antara peta kerawanan atau hasil dari pemodelan dengan kejadian sesungguhnya.

Hasil uji independen antara dua faktor dengan menggunakan crosstab antara model yang dihasilkan dengan kejadian demam berdarah yang sesungguhnya di lapangan, diperoleh hasil besarnya koefisien contingensi $(\mathrm{C})=0,558$.

Untuk mengetahui keeratan hubungan antara model dengan kejadian sesungguhnya maka nilai koefisien contingensi perlu dibandingkan dengan nilai koefisien contingensi maksimum ( $\mathrm{CmaKs}$ ) yang bisa terjadi. Makin dekat harga $\mathrm{C}$ dengan Cmaks maka makin besar derajat assosiasi antara 2 faktor. Dari hasil perhitungan diperoleh nilai Cmaks $=0,816$ dan nilai $\mathrm{C}=0,558$ nampak bahwa derajat hubungannya besar.

Model yang telah dihasilkan diharapkan dapat ikut membantu dalam usaha perencanaan pecegahan wabah DBD. Dalam perkembangannya, ada beberapa variabel yang menentukan terjadinya wabah demam berdarah. Pertama, nyamuk sebagai vektor (penular penyakit) yang bertelur pada genangan yang timbul akibat musim hujan. Telur menetaskan larva dan selanjutnya tumbuh dan berkembang menjadi nyamuk dewasa. Virus Dengue akan hidup dalam tubuh nyamuk ini.

Kedua, faktor lingkungan, yaitu lingkungan pekarangan yang tidak bersih, seperti bak mandi yang jarang dikuras, pot bunga, genangan air di berbagai tempat, nyamuk sampah terutama ban bekas, batok kelapa, potongan bambu, drum, kaleng-kaleng bekas, botol-botol yang dapat menampung air dalam jangka waktu yang lama. Perlu diketahui juga jenis nyamuk ini adalah jenis nyamuk "elite" yang hanya bisa berkembang biak pada air yang bersih dan jernih.

Ketiga, faktor iklim dan musim, dimana demam berdarah akan muncul setiap tahun sebagai ancaman yang serius bagi masyarakat kita. Keempat, faktor manusia, yang kemungkinan dapat tertular atau terjangkiti dan kemudian menjadi penderita demam berdarah.

Nyamuk Aedes aegypti menghisap darah manusia, nyamuk ini dikenal memiliki gigitan yang aktif sekali. Terutama pada waktu pagi atau sore hari. Dalam beberapa menit saja gigitannya berpindah-pindah mencapai puluhan orang 
yang sedang berada di suatu tempat kumpulan orang. Oleh karena itu nyamuk Aedes aegypti tergolong sebagai nyamuk dengan tingkat daya tular yang sangat aktif.

Kepadatan populasi nyamuk ini sejalan dengan tingkat kepadatan penduduk dengan lingkungan yang tidak terpelihara. Satu hal yang penting untuk dimengerti lingkungan dan faktor iklim yang panas dan lembab akibat musim hujan darat memperpanjang umur nyamuk Aedes aegypti. Sekali saja nyamuk ini mengandung virus dengue maka selama hidupnya akan mampu menularkan penyakit demam berdarah.

Sebagai langkah preventif dan antisipasi maka tidak ada alasannya bila kita semua memiliki kewaspadaan dini terhadap ancaman wabah demam berdarah ini. Masyarakat diminta memiliki kepedulian terhadap kebersihan lingkungan (sanitasi) sehingga nyamuk Aedes aegypti tidak mampu berkembang.

Tidak terlalu muluk apabila mulai dari sekarang masyarakat harus mulai ikut aktif membantu pemerintah dalam usaha-usaha pencegahan penyakit yang dapat dipengaruhi oleh perubahan iklim ini. Yaitu dengan cara "memotong" siklus perkembangbiakan nyamuk atau bahkan menghilangkan semua habitat nyamuk yang ada. Kapan kondisi aman terhadap ancaman penyakit tersebut tercapai? Hasilnya sangat ditentukan oleh partisipasi masyarakat dalam mengantisipasi keadaan tersebut.

\section{SIMPULAN}

1. Berdasarkan hasil pengolahan dan analisis dengan SIG, 8 parameter yang dipakai yaitu kepadatan permukiman, pola permukiman, jarak permukiman dengan sungai, frekuensi membersihkan bak penampungan air, pola pembuangan sampah, kondisi drainase, fogging dan keberadaan jumantik, seluruhnya memiliki hubungan yang assosiasi sebagian (partial corespondence) dengan kejadian DBD.

2. SIG dapat digunakan untuk membuat pemodelan spasial kerawanan wilayah terhadap DBD sehingga dapat dihasilkan peta kerawanan yang dapat digunakan untuk membantu perencanaan penanggulangan dan pecegahan wabah DBD.

3. Pemodelan spasial kerawanan wilayah terhadap demam berdarah di Kecamatan Depok menghasilkan 3 kelas kerawanan yaitu, agak rawan dengan luas sebesar 250,93 $\mathrm{Ha}(15,02 \%)$, rawan dengan luas sebesar 829,82 $\mathrm{Ha}$ $(49,67 \%)$, sangat rawan 589,87 $\mathrm{Ha}(35,31 \%)$.

4. Pengujian dengan menggunakan analisis crosstab dan korelasi terhadap model spasial kerawanan wilayah terhadap demam berdarah yang telah dihasilkan, dengan kejadian demam berdarah yang sesungguhnya di lapangan memberikan hasil bahwa nilai $\mathrm{C}$ (Koefisien kontingensi) $=0,558$ ada hubungan positif antara model dengan kejadian sesungguhnya di lapangan dan model dapat diterima. 
Beberapa simpulan penelitian adalah sebagai berikut:

1. Perlu dilakukan pengujian terhadap parameter-parameter lainnya seperti mobilitas penduduk yang kemungkinan memiliki pengaruh yang lebih besar jika dibandingkan dengan parameter lingkungan dan penduduk yang digunakan pada penelitian ini.

2. Perlu terus dilakukan pengelolaan lingkungan dan penyuluhan kepada masyarakat untuk mengurangi kerawanan wilayah terhadap demam berdarah dan lebih meminimalisir wabah demam berdarah di lingkungan Kecamatan Depok pada khususnya dan di Yogyakarta pada umumn

\section{DAFTAR PUSTAKA}

Adrian Ong and Mya Sandar. (2007). Fatal Dengue Hemorrhagic Fever in Adults During a Dengue Epidemic in Singapore. International Journal of Infectius Disease. Volue II. Issue 3. Pages 263-267.

Andianasolo, Haja and Bohra, Alpana. (2001). Apllication of GIS in Modelling of Dengue Risk Based on Socio-Cultural data : Case of Jalor, Rajasthan, India. Paper presented at the $22^{\text {nd }}$ Asian Conference on Remote Sensing., Singapore Institute of Surveyors and Valuers (SISV).

Andrew Haines, Anthony J. McMichael and Paul R. Epstein. (2000). Global Climate Change and Health, Canada's Leading Medical Journal, September 19, 2000; 163 (6)

Anis Fuad. (2007). Peran SIG untuk Kesehatan, Makalah Seminar, disajikan dalam seminar Peranan Kesehatan Masyarakat dalam Penanggulangan Bencana

Barbazan, Philippe. (2003). Dengue Haemorrhagic Fever (DHF) in the Central Plain of Thailand. Remote Sensing and GIS to Identify Factors and Indicators Related to Dengue Transmission. Thailand: The Center for Vaccine Development, Mahidol University.

Clara B. Ocampo And Dawn M. Wesson. (2004). Population Dynamics Of Aedes Aegypti From A Dengue Hyperendemic Urban Setting In Colombia.The American Society Of Tropical Medicine And Hygiene. Pp. 506-513.

Departemen Kesehatan RI. (2007). Laporan Tahunan Direktorat P2ML, Penyakit Menular. [Online]. Tersedia:http/www.depkes.go.id. (Juli 2007).

Fabián Méndez and Mauricio Barreto. (2006). Human And Mosquito Infections By Dengue Viruses During And After Epidemics In A Dengue-Endemic Region Of Colombia. The American Society Of Tropical Medicine And Hygiene. Pp. 678-683.

Gentilini, Brousse, Amat rose, Felix and paris. (1984). Travel in The Tropics the Infection Risk. Basle, Switzerland: F. Hoffmann. La Roche and Co. Limited Company.

Goh. (2002). Surveillance For Dengue Fever/Dengue Haemorrhagic Fever in Singapore, Singapore. Epidemiological News Bulletin, Vol 28. No 5.

Mantra, Ida Bagus. (2001). Langkah - Langkah Penelitian Survai, Usulan Penelitian, dan Laporan Penelitian. Yogyakarta: Fakultas Geografi UGM. 
Manson Bahr, and Apted. (1982). Manson's Tropical Diseases. Eighteenth Edition. The English Language Book Society and Bailliere Tindall, London.

Mohammad Ali and Yukiko Wagatsuma. (2003). Use Of A Geographic Information System For Defining Spatial Risk For Dengue Transmission In Bangladesh: Role For Aedes Albopictus In An Urban Outbreak. The American Society Of Tropical Medicine And Hygiene. Pp. 634-640.

Nasry, Noor. 1997. Pengantar Epidemiologi Penyakit Menular. Jakarta: Rineka Cipta.

Sudjana. (1992). Metoda Statistika. Edisi ke 5. Bandung: Transito.

Susumutu Hotta. (1978). Dangue And Related Arboviruses. Kobe: University School of Medicine.

WHO. (2003). Dangue and Dangue Haemorrhagic Fever. Who Report on Global Surveillance of Epidemic-prone Infectious Diseases. Chapter 6.

Wil Gesler. (2002). The Uses Of Spatial Analysis In Medical Geography. Social Science \& Medicine, Volume 23, Issue 10.Pages 963-973.

Yoshio Tsuda and Wannapa Suwonkerd . (2006). Different Spatial Distribution Of Aedes Aegypti And Aedes Albopictus Along An Urban-Rural Gradient And The Relating Environmental Factors Examined In Three Villages In Northern Thailand. Journal Of The American Mosquito Control Association. (pp. 222-228). 